\title{
Intermediate-depth earthquakes and the connection of the seismicity with metamorphism and deep fluid regime in subduction zone for the North Island of New Zealand
}

\author{
Margarita A. Nikitina*1 \\ Mikhail V. Rodkin ${ }^{1,2,3}$
}

\author{
${ }^{1}$ Institute of Earthquake Prediction Theory and Mathematical \\ Geophysics, Russian Academy of Sciences, Moscow, Russia \\ ${ }^{2}$ Institute of Marine Geology and Geophysics, Far Eastern Branch, \\ Russian Academy of Sciences, Yuzhno-Sakhalinsk, Russia \\ ${ }^{3}$ Oil and Gas Research Institute, Russian Academy of Sciences, \\ Moscow, Russia \\ *E-mail: margarita@mitp.ru
}

\begin{abstract}
Rus PDF
We applied descriptive statistics to the distributions of intermediate-depth earthquakes for a well-studied area of the North Island of New Zealand. Data on the density of the number of earthquakes are studied in the coordinates: depth - distance from the upper boundary of the submerged plate. This approach shows that some clusters of hypocenters are confined to the upper boundary of the subduction plate, while others are significantly distant from this boundary. At the same time, structures of sharply increased earthquakes density are distinguished. It can be interpreted through certain quasi-linear relations between pressure and temperature in subduction slab. Future studies can check the correlations between these structures and particular fronts of metamorphic transformations in immersed plates. Also note that the seismogenic structure can be quite confidently distinguished by spatial distribution of the density of earthquakes. This peak is located at the region near the upper boundary of the subduction slab under the zone of arc volcanism. In the southern part of the studied subduction zone, where such volcanism is not developed, such seismically active structure is not observed. The obtained data in comparison with the data for other subduction zones may be useful for choosing from alternative models of deep and intermediate-depth seismicity that is most consistent with modern seismological data.
\end{abstract}

\section{Keywords}

intermediate-depth earthquakes, subduction zone, New Zealand, metamorphism, dehydrations reactions

For citation: Nikitina M.A., Rodkin M.V. Intermediate-depth earthquakes and the connection of the seismicity with metamorphism and deep fluid regime in subduction zone for the North Island of New Zealand. Geosystems of Transition Zones, 2020, vol. 4, no. 1, p. 103-115. (In Russian). https://doi.org/10.30730/2541-8912.2020.4.1.103-115

Для цитирования: Никитина М.А., Родкин М.В. Среднеглубинные землетрясения и связь сейсмичности зоны субдукции с метаморфизмом и глубинным флюидным режимом для Северного острова Новой Зеландии. Геосистемы переходных зон. 2020. Т. 4, № 1. С. 103-115. https://doi.org/10.30730/2541-8912.2020.4.1.103-115 
1. Abers G.A. 2000. Hydrated subducted crust at 100-250 km depth. Earth and Planetary Science Letters, $176(3-$ 4): 323-330. https://doi.org/10.1016/S0012-821X(00)00007-8

2. Barnes P.M., Lamarche G., Bialas J., Henrys S., Pecher I., Netzeband G.L., Crutchley G. 2010. Tectonic and geological framework for gas hydrates and cold seeps on the Hikurangi subduction margin, New Zealand. Marine Geology, 272(1-4): 26-48. https://doi.org/10.1016/j.margeo.2009.03.012

3. Burtman V.S., Molnar P. 1993. Geological and geophysical evidence for deep subduction of continental crust beneath the Pamir. Geological Society of America Special Papers, 281: 1-76. https://doi.org/10.1130/spe281-p1

4. Davey F.J., Ristau J. 2011. Fore-arc mantle wedge seismicity under northeast New Zealand. Tectonophysics, 509(3-4): 272-279. https://doi.org/10.1016/j.tecto.2011.06.017

5. Davies J.H. 1999. The role of hydraulic fractures and intermediate-depth earthquakes in generating subductionzone magmatism. Nature, 398(6723): 142-145. https://doi.org/10.1038/18202

6. Fagereng A., Ellis S. 2009. On factors controlling the depth of interseismic coupling on the Hikurangi subduction interface, New Zealand. Earth and Planetary Science Letters, 278(1-2): 120-130. https://doi.org/10.1016/j.epsl.2008.11.033

7. Giba M., Walsh J.J., Nicol A., Mouslopoulou V., Seebeck H. 2013. Investigation of the spatio-temporal relationship between normal faulting and arc volcanism on million-year time scales. $J$. of the Geological Society, 170(6): 951-962. https://doi.org/10.1144/jgs2012-121

8. Hacker B.R., Peacock S.M., Abers G.A., Holloway S.D. 2003. Subduction factory. 2. Are intermediate-depth earthquakes in subducting slabs linked to metamorphic dehydration reactions? J. of Geophysical Research: Solid Earth, 108(B1): 2030. https://doi.org/10.1029/2001JB001129

9. Hayes G.P., Moore G.L., Portner D.E., Hearne M., Flamme H., Furtney M., Smoczyk G.M. 2018. Slab2, a comprehensive subduction zone geometry model. Science, 362(6410): 58-61. https://doi.org/10.1126/science.aat4723

10. Kalinin V.A., Rodkin M.V. 1982. Fizicheskaia model' glubokofokusnykh zemletriasenii [Physical model of deep-focus earthquakes]. Izv. AN SSSR. Fizika Zemli [Bulletin of the USSR Academy of Sciences. Physics of Solid Earth], 8: 3-12.

11. Kalinin V.A., Rodkin M.V. 1986. [On relation of motions orientations in the centers of deep-focus earthquakes with Benioff zones morphology]. Izv. AN SSSR. Fizika Zemli [Bulletin of the USSR Academy of Sciences. Physics of Solid Earth], 1: 3-11.

12. Kalinin V.A., Rodkin M.V. 1989. The quantitative deep earthquakes model. In: High Pressure Investigations in Geosciences. Berlin: Academie-Verlag, 213-217.

13. Kalinin V.A., Rodkin M.V., Tomashevskaia I.S. 1989. Geodinamicheskie effekty fiziko-khimicheskikh prevrashchenii v tverdoi srede [Geodynamic effects of physical and chemical transformations in the solid medium]. Moscow: Nauka, $157 \mathrm{p}$.

14. Kirby S., Engdahl R.E., Denlinger R. 1996. Intermediate-depth intraslab earthquakes and arc volcanism as physical expressions of crustal and uppermost mantle metamorphism in subducting slabs. Subduction: Top to Bottom, 96: 195-214. https://doi.org/10.1029/GM096p0195

15. Kuz'min M.I., Khlebopros R.G., Didenko A.N., Kozlova S.G., Zakhvataev V.E. 2019. [A possible relationship between deep-focus earthquakes and structure transition of submolecular $\mathrm{SiO}_{2}$ fragments in the rocks of a subducting oceanic plate]. Geologiia i geofizika = Russian Geology and Geophysics, 60(3): 285-300. http://dx.doi.org/10.15372/GiG2019038

16. Li W., Chen Y., Yuan X., Schurr B., Mechie J., Oimahmadov I., Fu B. 2018. Continental lithospheric subduction and intermediate-depth seismicity: constraints from S-wave velocity structures in the Pamir and Hindu Kush. Earth and Planetary Science Letters, 482: 478-489. https://doi.org/10.1016/j.eps1.2017.11.031.

17. Miiamura S. 1972. Seismichnost' Zemli [Seismicity of the Earth]. In: Zemnaia kora i verkhniaia mantiia [The Earth's Crust and Upper Mantle]. Moscow: Mir Publ., 93-103.

18. Okazaki K., Hirth G. 2016. Dehydration of lawsonite could directly trigger earthquakes in subducting oceanic crust. Nature, 530(7588): 81-84. https://doi.org/10.1038/nature16501

19. Peacock S.M. 1996. Thermal and petrologic structure of subduction zones. Subduction: Top to Bottom, 96: 119-133. https://doi.org/10.1029/GM096p0119

20. Reyners M., Eberhart-Phillips D. 2009. Small earthquakes provide insight into plate coupling and fluid distribution in the Hikurangi subduction zone, New Zealand. Earth and Planetary Science Letters, 282(1-4): 299-305. https://doi.org/10.1016/j.eps1.2009.03.034

21. Reyners M., Eberhart-Phillips D., Bannister S. 2011. Tracking repeated subduction of the Hikurangi Plateau beneath New Zealand. Earth and Planetary Science Letters, 311(1-2): 165-171. https://doi.org/10.1016/j.eps1.2011.09.011

22. Rodkin M.V. 1993. Rol' glubinnogo fliuidnogo rezhima v geodinamike i seismotektonike [Role of deep fluid regime in geodynamics and seismotectonics]. Moscow: Nats. geofiz. komitet [National geophysical committee], $194 \mathrm{p}$. 
23. Rodkin M.V., Rukavishnikova T.A. 2015. Oil-formation center as non-equilibrium dynamic system - the model and its comparison to experimental data. Geologiya Nefti $i$ Gaza = Oil and Gas Geology, 3: 63-68.

24. Rodkin M.V., Rundkvist D.V. 2017. Geofliuidogeodinamika. Prilozhenie k seismologii, tektonike, protsessam rudo- i neftegeneza [Geofluids and geodynamics. Application to seismology, tectonics, process of ore and oilgenesis]: monograph. Dolgoprudny: Intellekt Publ., 288 p.

25. Rodkin M.V., Tikhonov I.N. 2016. The typical seismic behavior in the vicinity of a large earthquake. Physics and Chemistry of the Earth, 95: 73-84. https://doi.org/10.1016/j.pce.2016.04.001

26. Romanova V.A., Os'kina G.N. 2011. Vizualizatsiia obrazovaniia poverkhnosti Kunsa [Visualization of Kuns surface forming]. Vestnik RUDN. Seriia Inzhenernye issledovaniia $=$ RUDN Journal. Engineering Researches, 4: $13-18$.

27. Stirling M., McVerry G., Gerstenberger M., Litchfield N., Van Dissen R., Berryman K., Lamarche G. 2012. National seismic hazard model for New Zealand: 2010 update. Bulletin of the Seismological Society of America, 102(4): 1514-1542. https://doi.org/10.1785/0120110170

28. Wadati K. 1928. Shallow and deep earthquakes. Geophysical Magazine, 1: 162-202.

29. Yamasaki T., Seno T. 2003. Double seismic zone and dehydration embrittlement of the subducting slab. J. of Geophysical Research: Solid Earth, 108(B4): 2212. https://doi.org/10.1029/2002JB001918 